\title{
Estimation of soil erosion and sediment yield concentration across the Kolleru Lake catchment using GIS
}

\author{
Meena Kumari Kolli ${ }^{1} \cdot$ Christian Opp $^{1} \cdot$ Michael Groll $^{1}$
}

Received: 17 June 2019 / Accepted: 20 January 2021

(c) The Author(s) 2021, corrected publication 2021

\begin{abstract}
Flat lakes with a large catchment area are especially affected by sediment inputs. The Kolleru Lake catchment (south-eastern India) with a surface area of approximately $6121 \mathrm{~km}^{2}$ belongs to such types of lake basins. The study's main objective was the assessment of both soil erosion and sediment yield concentration rate of the Kolleru catchment. The study was conducted using the revised universal soil loss equation (RUSLE) model due to its simple and good applicability for soil erosion estimation. Data such as rainfall, soil texture, topography, crop cover management, and support practice factor were integrated into the modeling using RUSLE and ArcGIS. Field data were used both to analyze the soil texture and the slope length factor. The results showed that average annual soil loss was estimated with $13.6 \mathrm{t} / \mathrm{ha} / \mathrm{year}$, classifying the Kolleru Lake Basin under a very high erosion rate category. About $38 \%$ of the catchment area has encountered slight soil loss. Areas covered with moderate, strong, severe, very severe erosion potential zones are $29 \%, 17 \%, 9 \%$, and $5.5 \%$, respectively. This study identified that upland areas with less vegetation cover exported high potential erosion rates. Unlike the soil loss, the sediment delivery ratio values for the catchment were not affected by land use, while it showed a strong relationship with the catchment drainage system. Whereas, the average annual sediment yield was determined with $7.61 \mathrm{t} / \mathrm{ha} / \mathrm{year}$, had identified with the same pattern of the soil erosion. Catchment topography, vegetation, drainage system, soil properties, and land use cover played a major role in exporting the highest sedimentation. The outcome of these studies can be used among others to identify critical erosion areas on a pixel basis for the planning of erosion management practices.
\end{abstract}

Keywords Soil erosion $\cdot$ Lake catchment $\cdot$ RUSLE $\cdot$ Remote sensing $\cdot$ GIS $\cdot$ Field data

\section{Introduction}

Soil erosion is a severe problem in agriculture and where it has the foremost economic aspect in developing countries (Erkossa et al. 2015; Mekonnen et al. 2016). However, soil erosion by runoff is a global land degradation problem (Oldeman 1992; Seutloali and Beckedahl 2015; Novara et al. 2016; Restrepo and Escobar 2018). The runoff is a major driving factor that accelerates the erosion rates from mountain to low-land regions (Civeira et al. 2016a, b; Dutta et al. 2017; Oliveira et al. 2019). Besides, human-induced erosion is a typical phenomenon of regions with intensive agricultural production, construction activities, mining, deforestation, high-density population, and a lack of

Meena Kumari Kolli

meenu.rgukt@gmail.com

1 Faculty of Geography, Philipps-Universität Marburg, Marburg, Germany integrated approaches (Amsalu et al. 2007; Mekonnen and Melesse 2011; Nyssen et al. 2015). This has been developed by significant changes in land use/land cover patterns. However, frequent land-use changes triggered surface runoff flows, reduce soil fertility, nutrient loss, and land degradation (Setegn et al. 2010; Gebremicael et al. 2013; Kim et al. 2013; Buendia et al. 2016; Hassen et al. 2016; Ang and Oeurng 2018). Many studies demonstrated that landuse changes alter the surface runoff and sediment yields at different spatial and temporal scales (Lin et al. 2015; Welde and Gebremariam 2017; Guzha et al. 2018). Therefore, sustainable development and strategic methods are needed to prevent more soil erosion and massive sediment loads.

Several methods for estimating the surface soil losses are known (Auerswald and Chesworth 2008; Brenner 2013). The RUSLE (Revised Universal Soil Loss Equation) is the most spread method and widely acceptable all over the world (Wishmeier and Smith 1978; Brown and Foster 1987; Sheikh et al. 2011; Addis and Klik 2015; Borelli et al. 2017) from 
the last few decades. Despite its disadvantages, the RUSLE model is best adapted to the developing countries where the application of other complex models could be limited to the lack of input data (Pervić et al. 2011). It has been used worldwide for a range of small scale (Fistikoglu and Harmancioglu 2002; Lee 2004; Pandey et al. 2009; Sheikh et al. 2011; Farhan et al. 2013) to large scale watersheds (Irvem et al. 2007; Chen et al. 2011; Kumar et al. 2012) to predict the longterm average annual rate of erosion. The RUSLE equation is a function of rainfall erosivity, soil erodability, slope length, crop management factor, and conservation practice (Sheikh et al. 2011). However, each factor has its characteristic influence on the erosion risk depending on the topography, vegetation cover, and soil type (Kumar et al. 2012; Farhan et al. 2013). Remote sensing and GIS applications are the best way to digitize the land cover maps (Rao 2003), including topography features.

The management of soil erosion and sedimentation losses is extremely complex due to large catchments spatial distribution (Mati and Veihe 2011). Therefore, it is essential to identify the critical erosion-prone areas for applying best management practices (BMPs). It is cost-effective to control soil erosion, mainly for an agricultural dominant land-use class (Shen et al. 2014; Sorando et al. 2019). However, there is a requirement of knowledge to prevent soil erosion in Kolleru lake basin studies are imperative (Jayanthi et al. 2006). At present, in the Kolleru Lake catchment, there is no gauge station to estimate soil loss; however, conventional methods are time consuming and cost-effective. Therefore, the USLE method was developed by (Wischmeier and Smith 1978) can be used to model the erosion rates in the Kolleru Lake catchment.

This study aims to ascertain both the spatial distribution of soil erosion and the sediment yield concentrations and to identify the highly polluted variability ranges. The objectives were achieved by the following tasks: (1) application of the RUSLE model to the entire Kolleru lake basin, (2) identification of the spatial distribution of soil erosion and sediment delivery ratio factors, (3) estimation of the sediment yield concentration across the Kolleru lake basin. However, due to the insufficient data, stream erosion and sediment deposition were not included in this study. Remote sensing data, such as land use classification, NDVI, elevation profile (DEM), and topography models, were used. At the same time, precipitation and soil texture data were acquired from the Indian Meteorological Department (IMD) and the Department of Agricultural Development, Andhra Pradesh, respectively.

\section{Study area}

The Kolleru Lake $\left(16^{\circ} 32^{\prime}-16^{\circ} 46^{\prime} \mathrm{N}, 81^{\circ} 04^{\prime}-81^{\circ} 24^{\prime} \mathrm{E}\right)$ is the largest freshwater lake in India (Fig. 1). It is also famous for a hospitable environment for aquatic life. Two large basins of Krishna and Godavari rivers formed its catchment. They act as natural flood reservoirs between these basins. The landform of the Kolleru lake catchment is mainly composed of upland (77.8\%) and deltaic $(22.1 \%)$ ecosystems (Azeez et al. 2011). The catchment of the lake expands up to $6,121 \mathrm{~km}^{2}$. It consists of mountains, streams, agricultural lands, industrial and built-up areas. The major soil groups in this area are Black Cotton Soils (57.6\%), Sandy Clay Loams (22.3\%), Red Soils (19.4\%), and minor soil group types are Coastal Sands (3\%), and Alkaline Soils (1\%) (Raju 2012). The mean annual temperature of the catchment area is $29^{\circ} \mathrm{C}$ (Patil 2005), with the minimum temperature ranges from 14 to $22{ }^{\circ} \mathrm{C}$, and the maximum temperature ranges from 35 to $46^{\circ} \mathrm{C}$. The mean annual precipitation is $1094 \mathrm{~mm}$. $70 \%$ of the precipitation acquires from June to September (Azeez et al. 2011). Additionally, the Kolleru lake receives water from the seasonal tributaries Tammileru and Budameru, and it has only one outlet channel: Upputeru, which connects the lake with the Bay of Bengal. Due to the recent advancement in man-made activities in this region, land-use changes have been accelerated erosion processes.

\section{Materials and methods}

The long-term analysis of soil erosion is carried out by the RUSLE method for this study (Wishmeier and Smith 1978). Five parameters are influencing the USLE equation. They are used in this study as raster formats such as rainfall erosivity $(R)$, soil erodability $(K)$, steepness factor (LS), crop factor $(C)$, and support practice factor $(P)$ (Auerswald 1992). The USLE equation can be expressed as:

$A=R \times K \times \operatorname{LS} \times C \times P$,

where $A$ is the average annual soil loss in (t/ha/year).

An overview of the used data and their contribution to the USLE shown in Figs. 2 and 3, reflecting the topographic and hydrographic conditions of the Kolleru Lake catchment, including the rain gauge stations. Figure 4 highlights the stream network in dependence on the scale of used pixels.

\section{Rainfall erosivity factor $(R)$}

The rainfall erosivity factor $(R)$ expresses the erosion rate, which was caused by the rainfall intensity, duration, and volume. In addition, velocity, the shape of raindrops, and the rain's kinetic energy to promote a high impact on soil erosion (Renard et al. 1997). There is a direct proportion between rainfall intensity and erosion; a high rate of rainfall intensity affects more runoff and subsequently results in more soil erosion. The $R$-factor varies between regions due to the precipitation patterns and slope conditions 

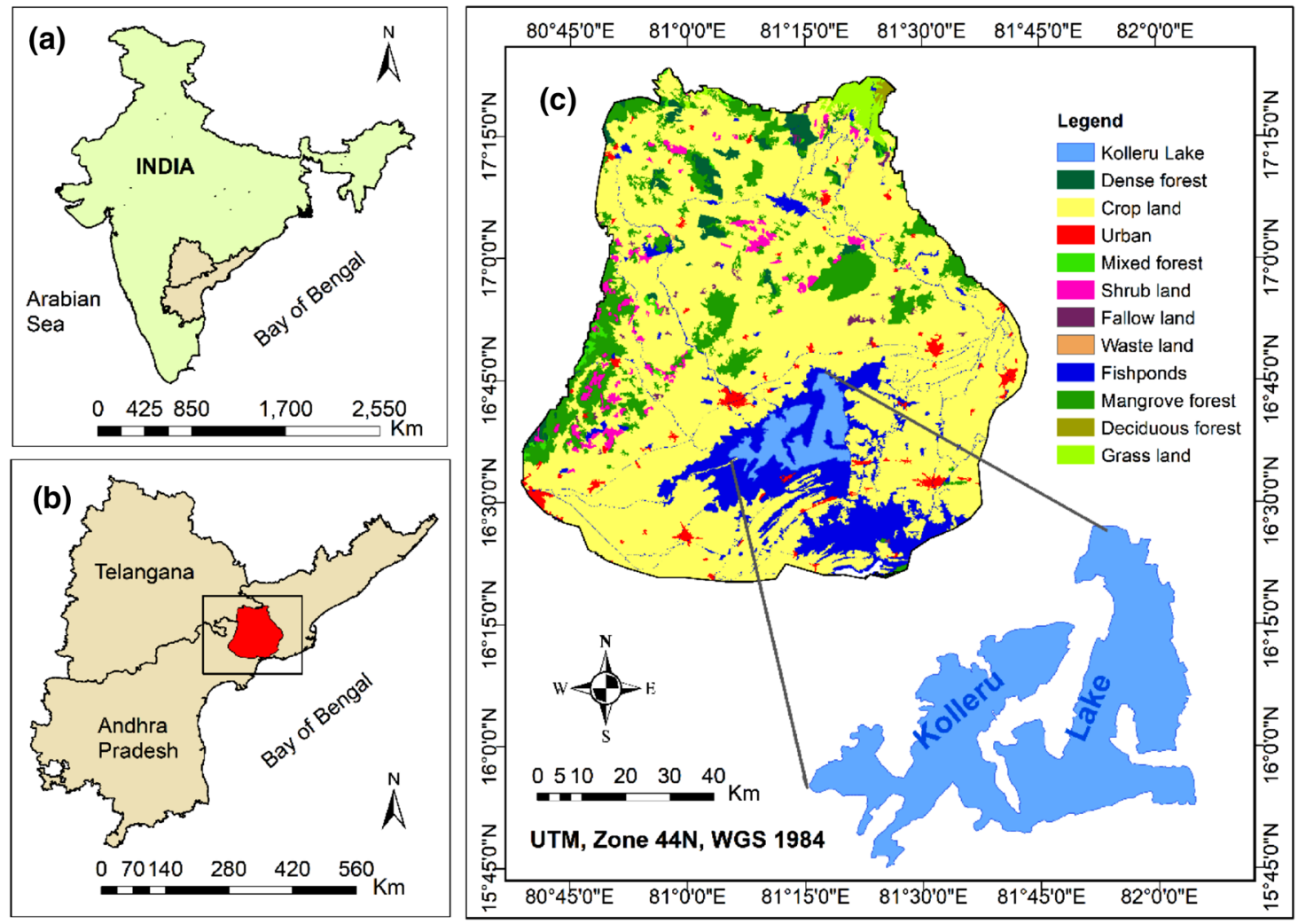

Fig. 1 Study area (Kolleru Lake) location map, a top-left (India map shapefile, NRSC-Hyderabad), b location of Kolleru Lake basin, $\mathbf{c}$ top-right (Land use map of Kolleru Lake basin, source: NRSC, Bhuvan)

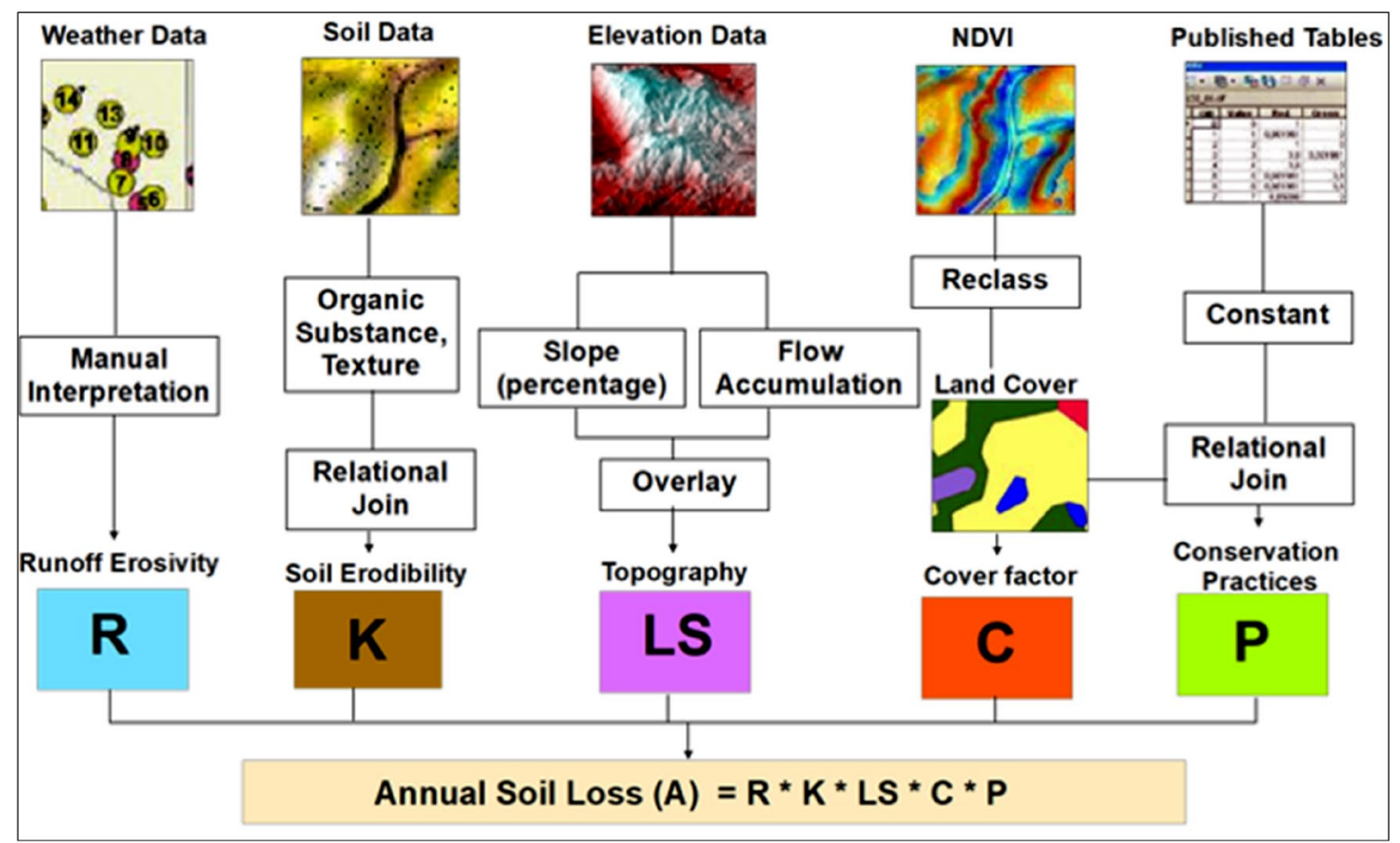

Fig. 2 Methodology flowchart of the study 
Fig. 3 Digitization of Kolleru Lake catchment along with tributaries using DEM (Digital Elevation Model), Cartosat-1, USGS Earth Explorer

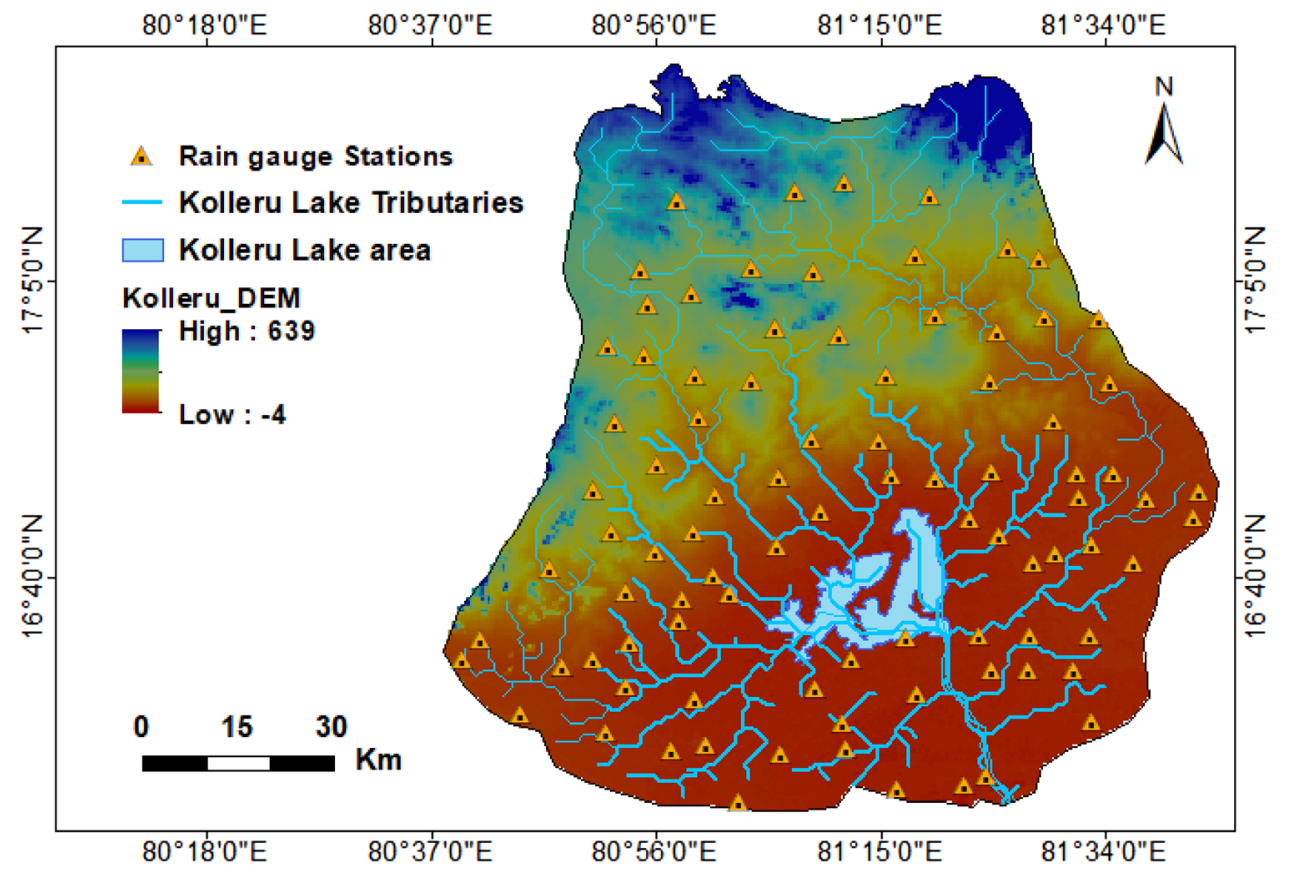

100 pixels

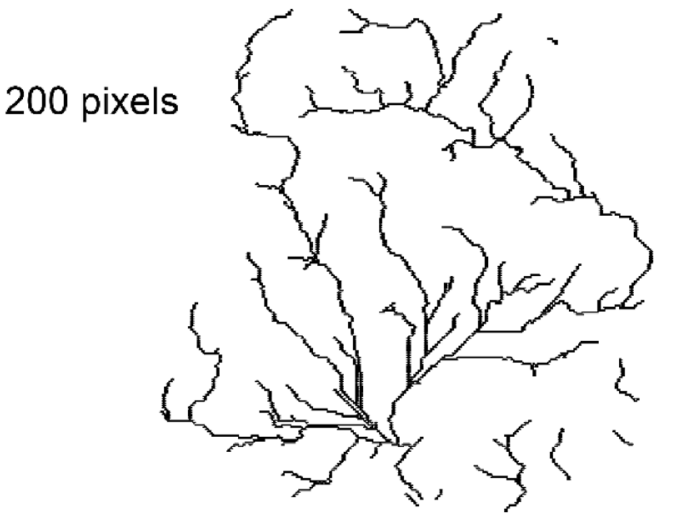

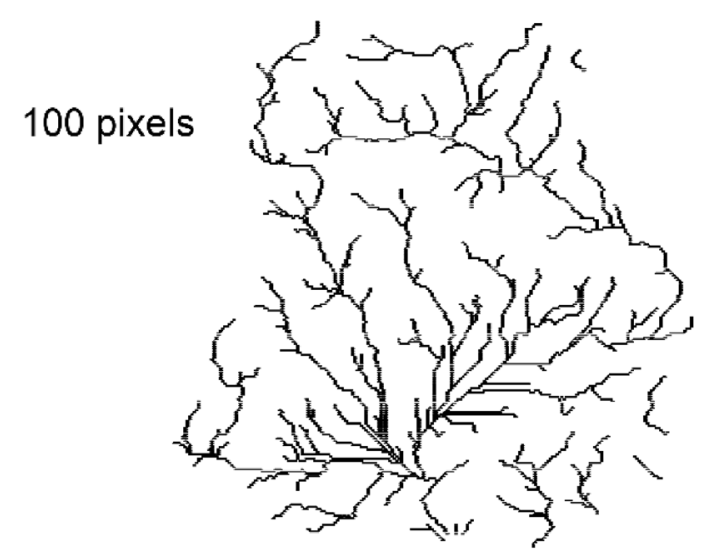

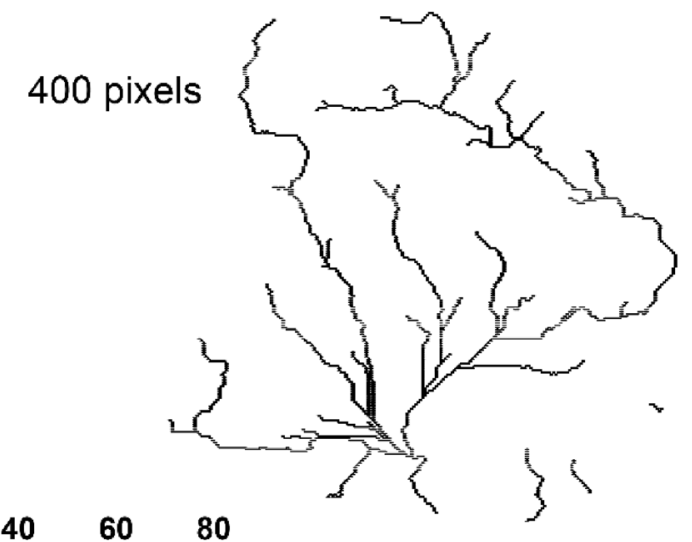

Kilometers

Fig. 4 Stream network of the Kolleru Lake catchment inferred from DEM 
(Farhan et al. 2013). Plain areas have low erosivity $R$ values because of low inclination, respectively low slope degree, whereas larger R-values indicate higher erosion amounts. Based on the climate data, the R-value represents the product of the rainfall energy $(E)$ and the maximum 30-min intensity (I30) (Brown and Foster 1987). On the other method, the $R$-value can be estimated by the Fourier

$\mathrm{LS}=(\text { Flow accumulation } \times \text { cell size } / 22.13)^{0.4} \times(\text { sin slope } / 0.0896)^{1.3}$,

index $(F)$, proposed by (Arnoldus 1977), to establish the erosion risk.

$F=\sum_{i=1}^{12} \frac{r_{i}^{2}}{P}$

where $r_{i}$ is the precipitation for 1 month, and $P$ is the annual precipitation.

The estimation of the $R$-value from $F$ can be determined by regression analysis. There are several regression equations for obtaining the $R$-factor. For this study, $R=0.3598$ $F^{1.9462}$ was used, because it was derived from climatic conditions similar to the study area proposed by (Zhang and Fu 2003).

\section{Slope length and steepness factor (LS)}

The LS factor in USLE represents the combined effect of the length $(L)$ and slope $(S)$ factors, merely depending on an area's topography. The LS-factor, which depends on flow direction, flow accumulation, and topography of the soil, was also considered while calculating the LS-factor. Slope length was defined by (Wischmeier and Smith 1978) as the distance from the point of origin of overland flow to the point where runoff becomes concentrated in a defined channel. Many equations have been developed to estimate the LS factor by (Wischmeier and Smith 1978), (Moore and Burch 1986a, b, c), (Griffin et al. 1988), (McCool et al. 1989), (Moore and Wilson 1992) and (Desmet and Govers 1996); however, they are confined to the distinctive characteristics of the topography of an area. Most of the algorithms are already implemented to calculate LS factor within GIS platforms, such as ArcGIS, SAGA GIS, GRASS, IDRISI, etc. However, according to (Desmet and Govers 1996), the LS factor derived from such methods gives higher values than the manual method. In another case study, LS values are derived from the GIS method were lower by $10-30 \%$ than obtained from the manual method (Hrabalikova and Janecek 2017), while 22\% higher values obtained by Griffin's method. Therefore, a comparison between different approaches determining the LS factor, based on manual and GIS methods, Hrabalikova and Janecek (2017) extensively documented that the best results obtained from Wischmeier's method, where a specific catchment area replaced slope length, and Moore's method.

The LS-factor was calculated for the catchment area of Kolleru Lake by following Eq. (3) proposed by (Moore and Burch 1986a, b).

where LS is the combined slope length and steepness factor, flow accumulation determines the upslope contributing area for a given cell, size of the cell was considered by the resolution of the DEM (for this study, a $30 \mathrm{~m}$ resolution DEM was available), and sin slope is slope degree value in $\sin$ (Moore and Burch 1986a). The stream network was derived from the DEM by changing the threshold value (Fig. 4). A detailed flow network can be observed from the smaller chosen value. For the calculation of the LS factor, 100 pixels threshold value has been used in this study.

\section{Support practice factor $(P)$}

P-factor indicates the effect of support practices on the average annual erosion rate. It represents the soil loss ratio with contouring and strip cropping to that with a straight row farming up-and-down slope (Renard et al. 1997). On the other hand, it indicates the rate of soil loss according to the various cultivated lands on the earth (Sheikh et al. 2011). For satisfactory results, the $P$-factor depends on contour, strip cropping, and terraces, which control erosion. According to the cultivating methods and slope conditions, the support practice factor value is shown in Table 1 (Shin 1999). The value of the $P$-factor ranges from 0 to 1 . Some agricultural support practices, such as contour farmland and surrounded by fish farmlands, occur within the Kolleru Lake catchment.

Table 1 Support practice factor according to the slope (after Shin 1999)

\begin{tabular}{llll}
\hline Slope $(\%)$ & Contouring & Strip cropping & Terracing \\
\hline $0.0-7.0$ & 0.55 & 0.27 & 0.10 \\
$7.0-11.3$ & 0.60 & 0.30 & 0.12 \\
$11.3-17.6$ & 0.80 & 0.40 & 0.16 \\
$17.6-26.8$ & 0.90 & 0.45 & 0.18 \\
$26.8>$ & 1.0 & 0.50 & 0.20 \\
\hline
\end{tabular}




\section{Soil erodibility factor $(K)$}

The soil erodibility factor $(K)$ expresses the disintegration of soil particles from parent rock material respectively the soil body under the action of rainfall intensity, wind, and natural or human activities results in sediment transport and runoff for a specific condition (Bancy et al. 2000; Pandey et al. 2007; Addis and Klik 2015). A wide range of soil eroded particles is known to belong predominantly to the silt and clay texture classes (Kim and Julien 2006). But also, sand particles are very less resistive to erosion (Buttafuoco et al. 2012; Karydas et al. 2013) because of their cohesive behavior towards the origin. Measurements can select the K-factor from field unit plots, for instance of $72.6 \mathrm{ft}$ long with $9 \%$ slope, continuously maintained fallow, tilled up and down the hill slope (Weesies 1998; Bagarello et al. 2009; Addis and Klik 2015). Direct measurements of runoff plots can also determine k values. However, field measurements are more accurate than other studies. For this study, the $\mathrm{K}$ factor was determined based on soil texture classes and organic matter contents proposed by Williams (1995). In this study, the soil samples (Fig. 5) were collected from different locations around the lake (c.f. Fig. 6), where the inflow of water debouches into the lake and the outflow of the water discharges into the sea (Figs. 5, 6). The corresponding $K$-values for the soil types were identified based on the particle size distribution and organic matter content in addition to the soil texture data from the Department of Agriculture Development, Andhra Pradesh, in India.

The field samples further soil texture classification was done based on the particle size distribution system followed by the sieve analysis method, in which the size of sieves range between 4.75 and $0.002 \mathrm{~mm}$ (IS 383 2020). Based on the degree of fineness, the soil particles were classified as sand, silt, and clay (in percentages) (Fig. 6). The organic matter content was determined based on the loss-on-ignition (LOI), which is the percentage weight loss of the soil sample due to ignition at a certain temperature. The erodibility values range from 0 to 1 , where 0 reflects soil with less water erosion, and 1 reflects soils with high water erosion. In this study, the $\mathrm{K}$ factor was derived from the following equation (Williams 1995) across the tributaries (Fig. 7).

$K_{\mathrm{USLE}}=f_{\text {csand }} \times f_{\text {cl - si }} \times f_{\text {orgc }} \times f_{\text {hisand }}$,

where $f_{\text {csand }}$ is a factor that lowers the $K$ indicator in soils with high coarse-sand content and increases it for soils with low sand content; $f_{\mathrm{cl}-\mathrm{si}}$ gives low soil erodibility factors for soils with high clay-to-silt ratios; $f_{\text {orgc }}$ reduces $K$ values in soils with high organic carbon content, while $f_{\text {hisand }}$ lowers $K$ values for soils with extremely high sand content:

$f_{\text {csand }}=\left(0.2+0.3 \cdot \exp \left[-0.256 \cdot m_{\mathrm{s}} \cdot\left(1-\frac{m_{\text {silt }}}{100}\right)\right]\right)$,

$f_{\mathrm{cl}-\mathrm{si}}=\left(\frac{m_{\mathrm{silt}}}{m_{\mathrm{c}}+m_{\mathrm{silt}}}\right)^{0.3}$

$f_{\text {orgc }}=\left(1-\frac{0.25 \cdot \operatorname{org} C}{\operatorname{org} C+\exp [3.72-2.95 \cdot \operatorname{org} C]}\right)$,

$f_{\text {hisand }}=\left(1-\frac{0.7 \cdot\left(1-\frac{m_{\mathrm{s}}}{100}\right)}{\left(1-\frac{m_{\mathrm{s}}}{100}\right)+\exp \left[-5.51+22.9 \cdot\left(1-\frac{m_{\mathrm{s}}}{100}\right)\right]}\right)$,

where, $f_{\mathrm{m}_{\mathrm{s}}}$ is the sand fraction content $(0.05-2.00 \mathrm{~mm}$ diameter $\%) ; m_{\text {silt }}$ is the silt fraction content $(0.002-0.05 \mathrm{~mm}$ diameter \%); $\mathrm{m}_{\mathrm{c}}$ is the clay fraction content $(<0.002 \mathrm{~mm}$ diameter \%); and orgC is the soil organic carbon (SOC) content (\%). Besides the soil classification, organic matter content was calculated by the loss of weight on ignition (LOI) method as follows:
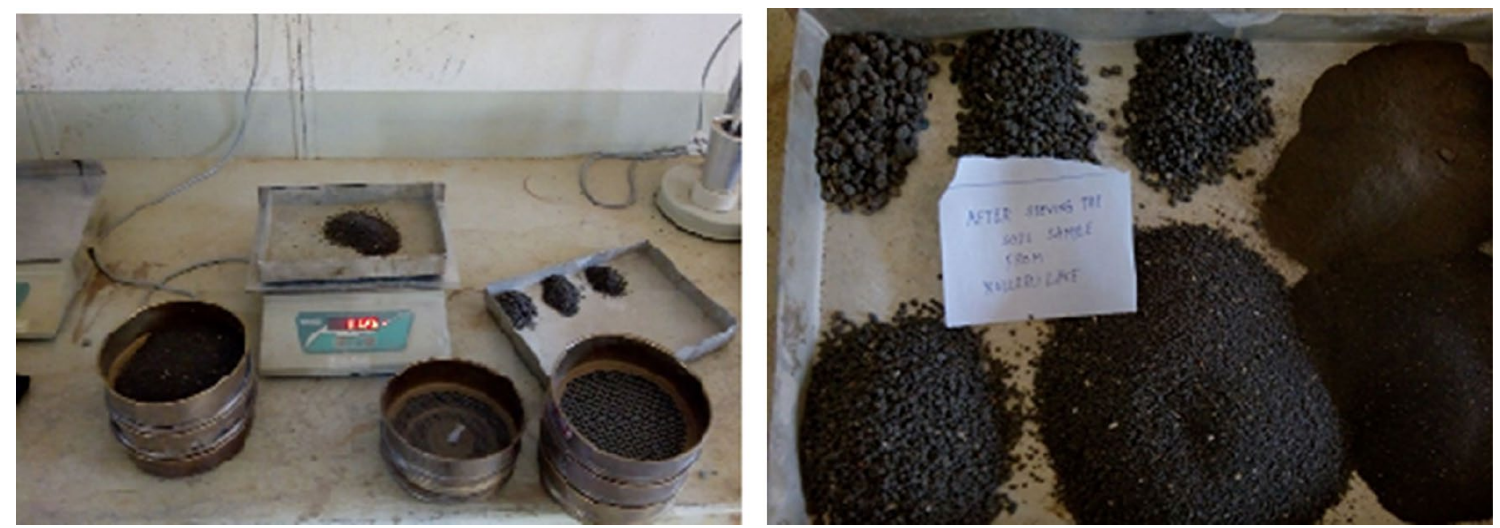

Fig. 5 Field data processing based on the sieve analysis method of Kolleru Lake 
Fig. 6 Texture classification of soil samples from Kolleru Lake (actual area shown as in DEM format) area based on the sieve analysis method

Fig. 7 NDVI classification of Kolleru Lake catchment
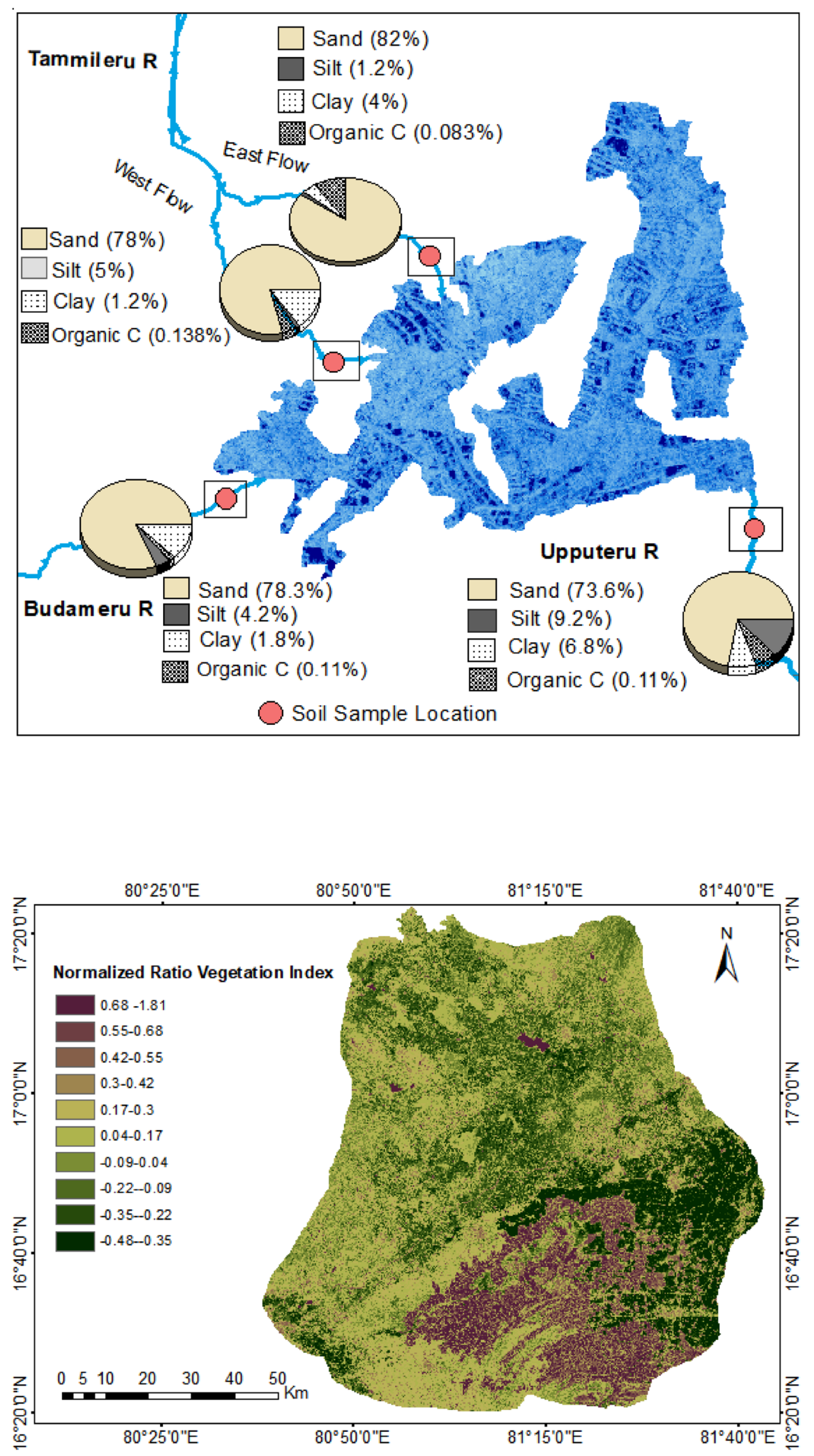
LOI $(\%)=\frac{\text { Weight at } 105^{\circ} \mathrm{C}-\text { Weight at } 360^{\circ} \mathrm{C}}{\text { Weight at } 105^{\circ} \mathrm{C}} \times 100$,

The estimation of organic matter from LOI is done by regression analysis. Using the Walkley-Black method is used to convert LOI to total carbon (Gelman et al. 2011). The equation as follows:

Total Organic $\mathrm{C}=(0.443 \times \mathrm{LOI})-2.77$.

The results are illustrated in Fig. 6.

\section{Crop and management factor (C)}

The crop management factor $(C)$ was determined from the existing land use and land cover patterns and NDVI (Kumar et al. 2012). It is expressed as the ratio of soil loss from land covered by the crop patterns under specific conditions to the corresponding loss from the plain area such as clean-tilled, waterbody and fallow land (Wischmeier and Smith 1978). The $C$-factor values range from 1 to 0 , where higher values represent no cover effect and more prone to erosion. In comparison, lower values represent the dense cover effect, results in less erosion (Erencin 2000). To find the effective crop factor based on the spatial and temporal variations, satellite remote sensing data were used (Prasannakumar et al. 2012). It depends on the type of crop cover and soil over the area of concern, and it considers the second major factor controlling erosion (Farhan et al. 2013). Despite the availability of land cover patterns, the values were assigned to each cover based on the type of land used.

\section{Predicting sediment yield}

Sediment yield prediction in a catchment embraces the determination of the amount of soil eroded and transferred from the point of interest at a given period. The statistical product between the surface soil erosion $(A)$ and the sediment delivery ratio $\left(D_{R}\right)$ is called sediment yield $\left(S_{\mathrm{y}}\right)$. The degree extent of $D_{R}$ values for an area is indiscriminately affected by catchment topography, vegetation cover, sediment sources, slope, soil texture, etc. (Richard et al. 1993; Lin et al. 2002; Fu et al. 2006). However, parameters such as land cover, slope, and catchment area have been mainly used in empirical equations for $D_{R}$ (Roehl 1962; Hadley et al. 1985; Kothyari and Jain 1997; Jain and Kothyari 2000; Fu et al. 2006).

$D_{R}$ in grid cells is the main function of the travel time of surface flow within the cell, which was extensively documented by (Ferro and Minacapilli 1995) and (Ferro 1997). A conformable grid with $30 \mathrm{~m} \times 30 \mathrm{~m}$ (in this study area, resolution of DEM, $30 \mathrm{~m}$ ) of cell size and a travel time of a surface flow is strongly dependent on land cover and topography characteristics of a catchment. It had been justified the relationship with $D_{R}$ (Jain and Kothyari 2000). Based on their studies, the land cover and topography has mainly considered in this study, and also assumed that grid cell existing in an overland region of a catchment. The empirical equation as follows:

$D_{R_{i}}=\exp \left(-\gamma t_{i}\right)$

where $\gamma$ is a constant coefficient for a given catchment and $t_{i}$ is the travel time (h) of surface flow from the $i_{\text {th }}$ grid to the nearest channel grid. Each grid's travel time in a channel can be estimated with the flow path if one knows lengths and velocities. In GIS (ESRI 1994) analysis, the eight-direction (D8) flow model can be achieved with the flow direction from one cell to a neighboring cell. There are eight valid output directions in a given grid cell relating to the eight adjacent cells into which the flow could take place. The flow direction is determined by the direction of steepest descent, or maximum drop, from each cell.

$S_{y}=\sum_{i=1}^{N} D_{R_{i}} A_{i}$

where $S_{y}$ is the sediment yield concentration, $A_{i}$ is the soil erosion over the catchment, and $D_{R_{i}}$ is the sediment delivery ratio.

\section{Results and discussion}

Maps for values of the RUSLE parameters, such as rainfall erosivity factor $(R)$, soil erodability factor $(K)$, length and slope inclination factor (LS), crop factor $(C)$, and support practice factor $(P)$, were overlaid to form a composite map of soil erosion $(A)$. The results discussed here based on the complete analysis of field and remote sensing data to estimate the soil erosion $(A)$, sediment delivery ratio $\left(D_{R_{i}}\right)$, and sediment yield concentration $\left(S_{y}\right)$ in the Kolleru Lake catchment. The results provide a general understanding of erosion risk levels and the rate of sediment yield concentrations in the catchment.

\section{Soil loss}

Figure 8 illustrates the spatial distribution of potential soil erosion risk map of Kolleru lake catchment. The annual average soil loss of the whole catchment was grouped into different classes, as Singh et al. (1992) suggested. About $38 \%$ of the area is encountered with slight soil loss $(<5 \mathrm{t} /$ ha/year). Whereas $29 \%$ of the area was prone to moderate 
Fig. 8 Soil erosion risk map of Kolleru Lake catchment using RUSLE method

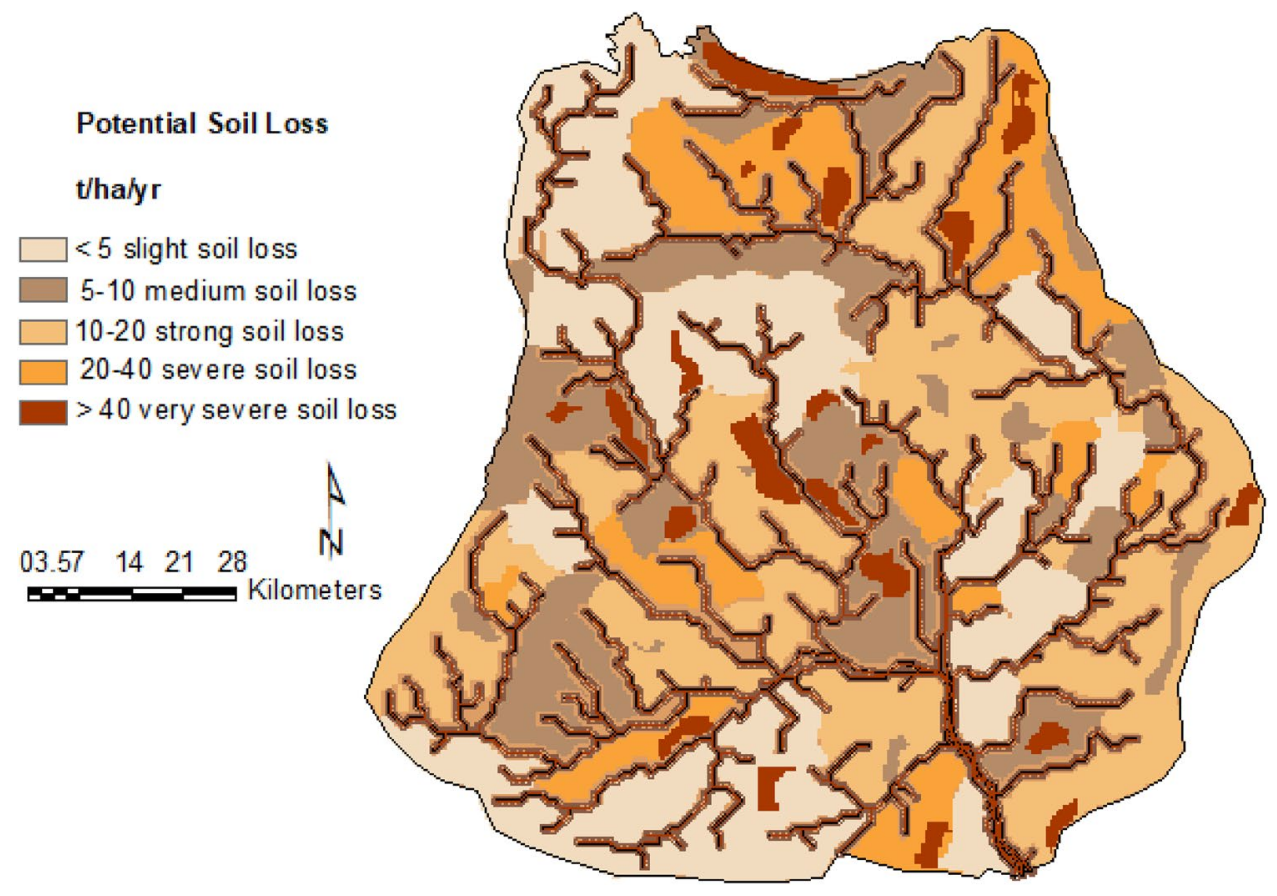

\section{Sediment delivery ratio}

soil loss $(5-10 \mathrm{t} / \mathrm{ha} / \mathrm{year}), 17 \%$ of the area was identified severe soil loss (20-40 t/ha/year), and 5.5\% area was under very severe soil loss (>40 t/ha/year) respectively. The observation of extreme soil loss areas is more than 5.5\% was already gone severe erosion due to its higher elevation slopes. The maximum soil loss areas are mainly concentrated in higher LS factor and conservation practice factors, where a large percent of the area still not covered by conservation measures. Meanwhile, the catchment area consists of less than $12 \%$ of vegetation cover that caused high erosion risk where forestland has the maximum water-retaining capacity while reducing the potential soil loss up to a certain extent. In addition, the studied soils are clayey in texture and non-porous in nature, which is more prone to runoff leading to more soil loss. In the Kolleru Lake catchment, topographic characteristics play a significant role in soil exports. In contrast, the proportion of the deltaic part is comprised of less than $22 \%$, relatively balanced in the downstream region.

Moreover, the study area belongs to the regions of maximum degradation of vegetation cover and changing weather parameters in Andhra Pradesh. However, frequent vegetation changes can promote erosion rates, especially in semiarid regions (Kumar et al. 2012). According to (Patil 2005), about 35.6 million tonnes of surface soil was eroded everyyear in Andhra Pradesh. Similar data were reported in other parts of the world (Civeira et al. 2016a, b; RodriguezIruretagoiena et al. 2016; Sanchís et al. 2015; Arenas-Lago et al. 2014; Silva et al. 2013), demonstrating the importance of this study.
The sediment delivery ratio $\left(D_{R}\right)$ showed a strong relationship between cell size and the nearest channel (Fig. 9). $D_{R}$ assumes that it has an inverse relationship with travel time, a function of travel length and velocity (Eq. 11). Because of the surface roughness and slope features, the same distance does not imply to all the cell values have the same $D_{R}$ with different travel times (Fu et al. 2006). The spatial distribution of $D_{R}$ is essential for identifying the potential soil loss areas and their respective sediment delivery sources (Jain and Kothyari 2000; Fu et al. 2006).

Unlike soil loss, the $D_{R}$ values obtained for the Kolleru lake catchment did not show a strong relation with land uses (Fig. 9), while it more likely tends to be affected by the catchment drainage system (Richard et al. 1993). It can be explained in Fig. 9, and those large $D_{R}$ values are associated with the steep headwater areas, which are likely to be stream network channels, while smaller $D_{R}$ values are found in overland regions, the channel networks surrounded that. The steep channel areas had the highest $D_{R}$ between 0.85 and 1, whereas the low $D_{R}$ values are far from the stream founded is 0.75 .

\section{Sediment yield}

The sediment yield concentrations mainly from surface runoff, erosion, vegetation type, soil and water conservation practices, and topographic factor. Figure 10 depicts the sediment yield distribution was classified into five categories channels. The average $D_{R}$ for the Kolleru lake catchment 
Fig. 9 Spatial distribution of sediment delivery ratio at Kolleru Lake catchment

\section{Legend}

Sediment Delivery Ratio

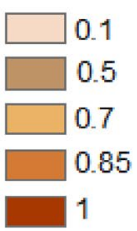

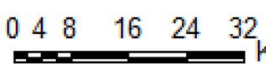

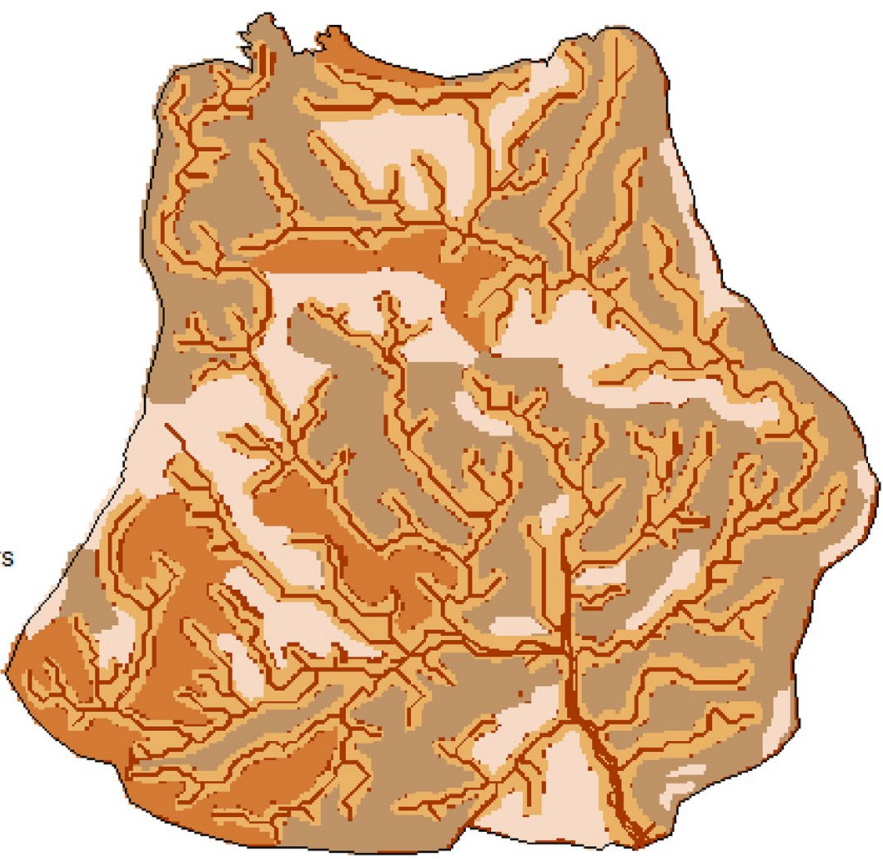

Fig. 10 Sediment yield $(\mathrm{t} / \mathrm{ha} /$ year) at Kolleru Lake catchment

\section{Legend

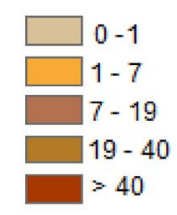

Sediment Yield (t/ha/yr)

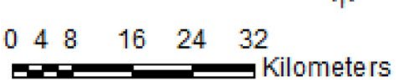

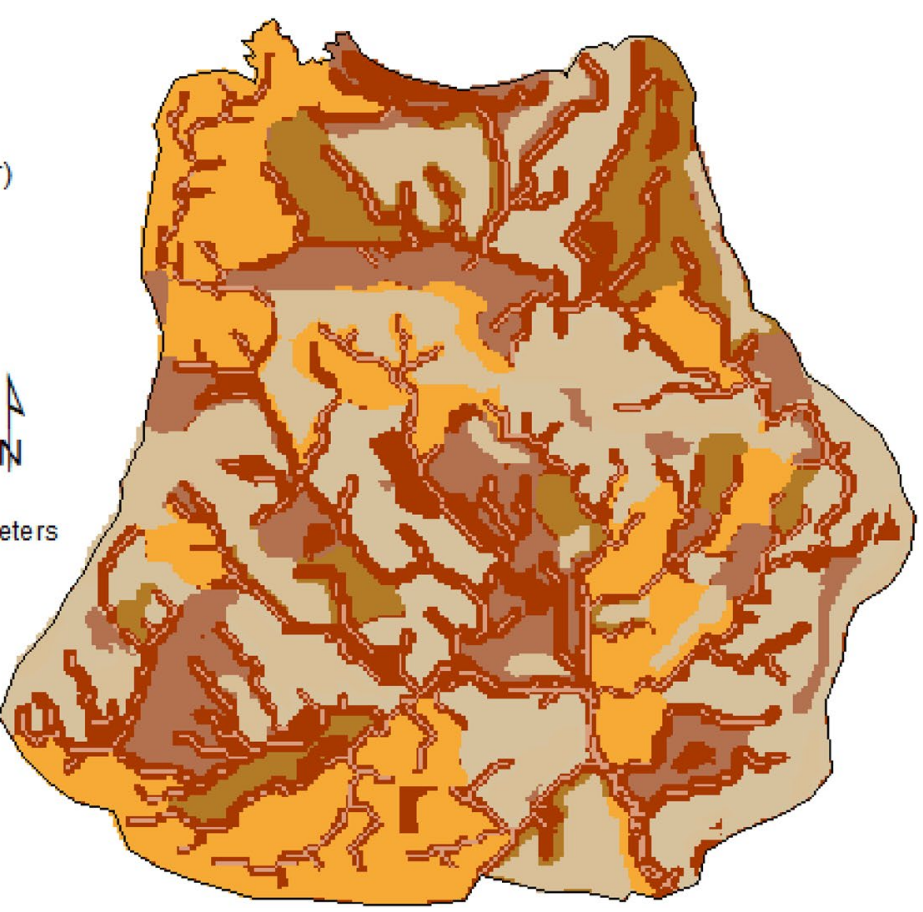

according to their proportion of distribution. The average annual sediment yield concentration in the Kolleru Lake catchment is found to be $7.61 \mathrm{t} / \mathrm{ha} /$ year. Whereas $27 \%$ of the area has encountered with slight sediment yield $(<1 \mathrm{t} /$ ha/year), $32 \%$ of the area has prone to moderate sediment yield (1-7 t/ha/year), $22 \%$ of the area has identified as strong sediment yield (7-19t/ha/year), while $13 \%$ of the area severe sediment yield (19-40 t/ha/year), and $4.5 \%$ of the area very severe sediment yield ( $>40 \mathrm{t} / \mathrm{ha} /$ year). The sediment yield distribution from the entire catchment was followed by the same pattern of soil erosion (Fig. 8); thereby, it was modified with the stream patterns similar to that of $D_{R}$ (Fig. 9). The sediment yield concentration was relatively high in croplands, particularly from paddy fields. Meanwhile, the cultivation on higher elevation slopes caused great soil erosion in the Kolleru catchment. Besides, the areas with high sediment 
yields are also concentrated in wastelands, and there the erosion rate is higher in uncovered areas. In the catchment area, red soils and sandy clay soils exported most sediment. This is referenced to the soil properties while indicating the depth, slope, texture pattern, erosion, and drainage.

Furthermore, agricultural and industrial activities are the major sources of surface erosion and, consequently, sedimentation and siltation within the Kolleru lake catchment (Azeez et al. 2011). According to (Narender 1993), eight major industries were located nearby the lake contributing about 7.2 million liters of industrial effluents containing suspended solids, organic acids, colloids, etc. led into the lake. Besides, Krishna and Godavari's perennial rivers drift down to the lake, about 68,000 tons of sediments (Azeez et al. 2011). As mentioned by own on-site observations, a substantial proportion of suspended sediments to the Kolleru lake comes from the river banks. Moreover, fishponds cultivation around the lake contains a high organic load, fertilizers, and pesticides (Narender 1993). The catchment confronts several other threats: siltation, eutrophication, and water circulation significantly affect the lake ecosystem (Rao and Pillala 2001; Sekhar et al. 2004; Rao et al. 2006). This study presents compiled RUSLE and GIS data and its analyses in different world areas previously reported (Cerqueir et al. 2011; Ribeiro et al. 2010; Quispe et al. 2012; Sánchiz et al. 2013).

\section{Conclusions}

This model helps identify the susceptible erosion-prone areas where the data's uncertainty is available that should be targeted for the agricultural management plans. The coupling of GIS and RUSLE models was used in an efficient procedure to estimate soil erosion and sediment yield concentration using and collecting the existing data of the Kolleru Lake basin with remote sensing images. The overall results are presented on a pixel-wise spatial distribution of the soil erosion and sediment yield rate in the Kolleru Lake basin. Upland areas exhibited much greater erosion rates to the stream channels than plain areas. Tributaries and streamlines of the catchment carry high sediment loads to the Kolleru lake and its outlet. The average annual soil loss was estimated at $13.6 \mathrm{t} / \mathrm{ha} /$ year classifying the basin into a very high soil erosion category. Combined with a detailed investigation of the vegetation maps, soil texture, rainfall intensity, and topographic features and using remote sensing and GIS techniques, it becomes possible to estimate the erosion losses accurately. Meanwhile, the average annual sediment yield of the basin was found to be $7.61 \mathrm{t} / \mathrm{ha} / \mathrm{year}$. Agricultural and industrial activities were found as major sources of soil erosion and sedimentation. It was identified that soil loss and sediment yield patterns are spatially connected, and the sediment yield was highly modified with the sediment delivery ratio. In this area, priority attention must be given to the adjacent streamlines, either application of buffer strips has been suggested to prevent more soil losses. The areas under the potential erosion soil losses need immediate attention from the agriculture management point of view, in combination with both detailed investigations of the vegetation maps, soil texture, rainfall intensity, and topographic features and using remote sensing and GIS techniques the estimation of soil erosion losses and sediment loads accurately.

Acknowledgements This research was carried out at the PhilippsUniversität Marburg (Germany) (Grant number: Marburg International Doctorate), supported by the DAAD. The authors would like to thank anonymous reviewers, and constructive comments improved the presentation of this paper.

Funding Open Access funding enabled and organized by Projekt DEAL.

Open Access This article is licensed under a Creative Commons Attribution 4.0 International License, which permits use, sharing, adaptation, distribution and reproduction in any medium or format, as long as you give appropriate credit to the original author(s) and the source, provide a link to the Creative Commons licence, and indicate if changes were made. The images or other third party material in this article are included in the article's Creative Commons licence, unless indicated otherwise in a credit line to the material. If material is not included in the article's Creative Commons licence and your intended use is not permitted by statutory regulation or exceeds the permitted use, you will need to obtain permission directly from the copyright holder. To view a copy of this licence, visit http://creativecommons.org/licenses/by/4.0/.

\section{References}

Addis HK, Klik A (2015) Predicting the spatial distribution of soil erodibility factor using USLE nomograph in an agricultural watershed, Ethiopia. Int Soil Water Conserv Res 3:282-290

Amssalu A, Stroosnijder L, de Graaf J (2007) Long-term dynamics in land resource use and the driving forces in the Beressa watershed, highlands of Ethiopia. J Environ Manag 83:448-459

Ang R, Oeurng C (2018) Simulating streamflow in an ungauged catchment of Tonlesap LakeBasin in Cambodia using Soil and Water Assessment Tool (SWAT) model. Water Sci 32:89-101

Arenas-Lago D, Vega FA, Silva LF, Andrade ML (2014) Copper distribution in surface and subsurface soil horizons. Environ Sci Pollut Res Int 21:10997-11008

Arnoldus HMJ (1977) Methodology used to determine the maximum potential average soil loss due to sheet and rill erosion in morocco: assessing soil degradation. FAO Soils Bull 34:8-9

Auerswald K (1984) Die Bestimmung von Faktorenwerten der Allgemeinen Bodenabtragsgleichung durch künstliche Starkregen Diss. TU München

Auerswald K (1992) Predicted and measured sediment loads of large watersheds in Bavaria. In: Proc. 5th Int. Symp. River Sedimentation, Karlsruhe, pp 1031-1036

Auerswald K (2008) Water erosion. In: Chesworth W (ed) The encyclopedia of soil science. Springer, Dordrecht, pp 817-822

Azeez PA, Kumar SA, Choudhury BC, Sastry VNVK, Upadhyay S, Reddy KM, Rao KK (2011) Report on the proposal for 
downsizing the Kolleru Wildlife sanctuary $(+5$ to +3 feet contour). Ministry of Environment and forests government of India.

Bagarello V, Stefano CD, Ferro V, Giuseppe G, Lovino M (2009) A Pedotransfer function for estimating the soil erodibility factor in Sicily. J Agric Eng 40(3):7-13

Bancy MM, Royston PCM, Francis NG, John NQ, Tim RB, Hans PL (2000) Assessment of erosion hazard with the USLE and GIS: a case study of the Upper Ewaso Ng' iro North basin of Kenya. Int J Appl Earth Obs Geoinf 2:78-86

Beskow S, Mello CR, Norton LD, Curi N, Viola MR, Avanzi JC (2009) Soil erosion prediction in the Grande River Basin Brazil using distributed modeling. CATENA 79:49-59

Bhatt R, Khera KL (2006) Effect of tillage and mode of straw mulch application on soil erosion in the sub-mountainous tract of Punjab, India. Soil tillage Res 88:107-115

Bojko O, Kabala C (2014) Loss-on-Ignition as an estimate of total organic carbon in the mountain soils. Pol J Soil Sci XLVII/2. PL (ISSN 0079-2985)

Borelli P, Panagos P, Märker M, Modugno S, Schütt B (2017) Assessment of the impacts of clear-cutting on soil loss by water erosion in Italian forests: first comprehensive monitoring and modeling approach. CATENA 149:770-781

Brenner C (2013) Monitoring and simulation of soil erosion in the Ethiopian Highlands on a plot scale. Diplomarbeit/Masterarbeit-Institut für Hydraulik und landeskulturelle Wasserwirtschaft (IHLW), BOKU-Universität für Bodenkultur

Bridgham SD, Megonigal JP, Keller JK, Bliss NB, Trettin C (2006) The carbon balance of North American Wetlands, vol 26, pp 889-916

Brown LC, Foster GR (1987) Storm erosivity using idealized intensity distributions. Trans ASAE 30:379-386

Buendia C, Bussi G, Tuset J, Vericat D, Sabater S, Palaub A, Batalla RJ (2016) Effects of afforestation on runoff and sediment load in an upland Mediterranean catchment. Sci Total Environ 540:144-157

Buttafuoco G, Conforti M, Aucelli PPC, Robustelli G, Scarciglia F (2012) Assessing spatial uncertainty in mapping soil erodibility factor using geostatistical stochastic simulation. Environ Earth Sci 66:1111-1125

Cerqueira B, Vega FA, Serra C, Silva LFO, Andrade ML (2011) Time of flight secondary ion mass spectrometry and high-resolution transmission electron microscopy/energy dispersive spectroscopy: a preliminary study of the distribution of cu2 + and cu2 $2+1$ $\mathrm{pb} 2+$ on a bt horizon surface. J Hazard Mater 195:422-431

Chen T, Niu RQ, Li PX, Zhang LP, Du B (2011) Regional soil erosion risk mapping using RUSLE, GIS, and remote sensing: a case study in Miyun Watershed, North China. Environ Earth Sci 63:533-541

Christopher KW, Michael CW (2013) Recent land-use change in the Western Corn Belt threatens grasslands and wetlands. Proc Natl Acad Sci 110:4134-4139

Civeira MS, Ramos CG, Oliveira MLS, Kautzmann RM, Taffarel SR, Teixeira EC, Silva LF (2016a) Nano-mineralogy of suspended sediment during the beginning of coal rejects spill. Chemosphere 145:142-147

Civeira M, Oliveira M, Hower J, Agudelo-Castañeda D, Taffarel S, Ramos C, Kautzmann R, Silva LF (2016b) Modification, adsorption, and geochemistry processes on altered minerals and amorphous phases on the nanometer scale: examples from copper mining refuse, touro, Spain. Environ Sci Pollut Res Int 23:6535-6545

Dabral PP, Baithuri N, Pandey A (2008) Soil Erosion Assessment in a Hilly Catchment of North Eastern India Using, GIS, and Remote Sensing. Water Resour Manage 22:1783-1798

Desmet PJJ, Govers G (1996) A GIS procedure for automatically calculating the USLE LS factor on topographically complex landscape units. J Soil Water Conserv 51:427-433
Dortch JM, Owen LA, Haneberg WC, Caffee MW, Dietsch C, Kamp U (2009) Nature and timing of large landslides in the Himalaya and Transhimalaya of northern India. Q Sci Rev 28:1037-1054

Dutta M, Saikia J, Taffarel SR, Waanders FB, de Medeiros D, Cutruneo CM, Saikia BK (2017) Environmental assessment and nano-mineralogical characterization of coal, overburden, and sediment from Indian coal mining acid drainage. Geosci Front $8: 1285-1297$

Erencin Z (2000) C-factor mapping using remote sensing and GIS. A case study of Lom Sak/Lom Kao, Thailand. International Institute for Aerospace Survey and Earth Sciences (ITC), Enschede/ Holland

Erkossa T, Wudneh A, Desalegn B, Taye G (2015) Linking soil erosion to on-site financial cost: lessons from watersheds in the Blue Nile basin. Solid Earth 6:765-774

ESRI (Environmental Systems Research Institute) (1994) Cell-based modeling with GRID. Environmental Systems Research Inc., Redlands

Farhan Y, Zregat D, Farhan I (2013) Spatial estimation of soil erosion risk using RUSLE approach, RS, and GIS techniques: a case study of Kufranja Watershed, Northern Jordan. J Water Resour Prot 2013(5):1247-1261

Ferro V (1997) Further remarks on a distributed approach to sediment delivery. Hydrol Sci J 42(5):633-647

Ferro V, Minacapilli M (1995) Sediment delivery processes at the basin scale. Hydrol Sci J 40(6):703-717

Fistikoglu O, Harmancioglu NB (2002) Integration of GIS with USLE in the assessment of soil erosion. Water Resour Manag 16:447-467

Fu G, Chen S, McCool DK (2006) Modeling the impacts of no-till practice on soil erosion and sediment yield with RUSLE, SEDD, and ArcView GIS. Soil Tillage Res 85:38-49

Gebremicael TG, Mohamed YA, Betrie GD, Zaag P, Teferi E (2013) Trend analysis of runoff and sediment fluxes in the Upper Blue Nile basin: a combined analysis of statistical tests, physicallybased models and land-use maps. J Hydrol 482:57-68

Gelman F, Binstock R, Halicz L (2011) Application of the WalkleyBlack titration for organic carbon quantification in organic-rich sedimentary rocks. The Ministry of National Infrastructures Geological Survey of Israel

Griffin ML, Beasley DB, Fletcher JJ, Foster GR (1988) Estimating soil loss on the topographically non-uniform field and farm units. J Soil Water Conserv 43:326-331

Guzha AC, Rufino MC, Okoth S, Jacobs S, Nóbrega RLB (2018) Impacts of land use and landcover change on surface runoff, discharge, and low flows: evidence from East Africa. J Hydrol Reg Stud 15:49-67

Hadley RF, Lai R, Onstad CA, Walling DE, Yair A (1985) Recent developments in erosion and sediment yield studies. UNESCO (IHP) Publication, Paris

Haigh M, Rawat JS (2012) Landslide disasters: seeking causes: a case study from Uttarakhand, India, Chapter 18, pp 218-253

Hassen MY, Assefa MM, Gete Z, Tena A (2016) Streamflow prediction uncertainty analysis and verification of the SWAT model in a tropical watershed. Environ Earth Sci 75:806

Hrabalíková M, Janeček M (2017) Comparison of different approaches to LS factor calculations based on a measured soil loss under simulated rainfall. Soil Water Res 12:69-77

Irvem A, Topaloglu F, Uygur V (2007) Estimating the spatial distribution of soil loss over the Seyhan River Basin in Turkey. J Hydrol $336: 30-37$

IS 383 (2020) Specification for Coarse and Fine Aggregates from natural sources for concrete, by Bureau of Indian Standards

Jain SK, Goel MK (2002) Assessing the vulnerability to soil erosion of the Ukai Dam catchments using remote sensing and GIS. Hydrol Sci J 47(1):31-40 
Jain MK, Kothyari UC (2000) Estimation of soil erosion and sediment yield using GIS. Hydrol Sci J 45(5):771-786

Jayanthi M, Rekha PN, Kavitha N, Ravichandran P (2006) Assessment of the impact of aquaculture on Kolleru Lake (India) using remote sensing and Geographical Information System. Aquac Res 37:1617-1626

Karydas CG, Petriolis M, Manakos I (2013) Evaluating alternative methods of soil erodibility mapping in the Mediterranean Island of Crete. Agriculture 2013(3):362-380

Kim HS, Julien PY (2006) Soil erosion modeling using RUSLE and GIS on the Imha Watershed. Water Eng Res 7:29-41

Kim J, Choi J, Choi C, Park S (2013) Impacts of changes in climate and land use/land cover under IPCC RCP scenarios on streamflow in the Hoeya River Basin, Korea. Sci Total Environ 452-453:181-195

Kothyari UC, Jain SK (1997) Sediment yield estimation using GIS. Hydrol Sci J 42(6):833-843

Kumar PV, Vijith H, Abinod S, Geetha N (2012) Estimation of soil erosion risk within a small mountainous sub-watershed in Kerala, India, using the Revised Universal Soil Loss Equation (RUSLE) and geo-information technology, vol 2, pp 209-215

Lee S (2004) Soil erosion assessment and its verification using the Universal Soil Loss Equation and geographic information system: a case study at Boun, Korea. Environ Geol 45(4):457-465

Lin CY, Lin WT, Chou WC (2002) Soil erosion prediction and sediment yield estimation: the Taiwan experience. Soil Tillage Res 68:143-152

Lin BQ, Chen XW, Yao HX, Chen Y, Liu MB, Gao L, James A (2015) Analyses of land-use change impacts on catchment runoff using different time indicators based on SWAT model. Ecol Indic 58:55-63

Mati BM, Veihe A (2011) Application of the USLE in a savannah environment: comparative experiences from East and WestAfrica. Singap J Trop Geogr 22:138-155

McCool DK, Foster GR, Mutchler CK, Meyer LD (1989) Revised slope length factor for the Universal Soil Loss Equation. Trans ASAE 32:1571-1576

Mekonnen MM, Melesse AM (2011) Soil erosion mapping and hotspot area identification using GIS and remote sensing in northwest Ethiopian highlands, near lake Tana. In: Melesse AM (ed) Nile river basin hydrology climate \& water use, pp 207-224

Mekonnen M, Keesstra SD, Baartman JEM, Stroosnijder L, Maroulis J (2016) Reducing sediment connectivity through man-made and natural sediment sinks in the Minizr catchment, Northwest Ethiopia. Land Degrad Dev 28:708-717

Moore ID, Burch GJ (1986b) Modeling erosion and deposition. Topogr Effects Trans Am Soc Agric Eng 29(6):1624-1630

Moore ID, Burch GJ (1986c) The physical basis of the slope factor in the universal soil loss equation. Soil Sci Soc Am J 50:1294-1298

Moore ID, Burch GJ (1986a) Physical basis of the length-slope factor in the universal soil loss equation1. Soil Sci Soc Am J 50:1294-1298

Moore ID, Wilson JP (1992) Length-slope factors for the revised universal soil loss equation: simplified method of estimation. J Soil Water Conserv 47:423-428

Narender K (1993) The broken mirror. Down to earth, vol 2, December 1993. www.downtoearth.org.in/node/31851

Nelson RG (2002) Biomass Bioenerg 22(5):349-363. https://doi.org/ 10.1016/S0961-9534(02)00006-5

Novara A, Keesstra S, Cerda A, Pereira P, Gristina L (2016) Understanding the role of soil erosion on co2-c loss using 13c isotropic signatures in abandoned Mediterranean agricultural land. Sci Total Environ 550:330-336

Nyssen J, Frankl A, Zenebe A, Deckers J, Poesen J (2015) Land management in the northern Ethiopian highlands: local and global perspectives; past, present, and future. Land Degrad Dev 26:759-764

Oldeman LR (1992). Global extent of soil degradation. ISRIC Biannual report 1991-1992. ISRIC, Wageningen

Oliveira MLS, Saikia BK, Da Boit K, Pinto D, Tutikian BF, Silva LFO (2019) River dynamics and nanoparticle formation: a comprehensive study on the nanoparticle geochemistry of suspended sediments in the Magdalena River, Caribbean Industrial Area. J Clean Prod 213:819-824

Pal I (2010) Rainfall trend in India and their impact on soil erosion and land management. A dissertation submitted for the degree of Doctor of Philosophy in the Department of Engineering at the University of Cambridge

Pandey A, Chowdary VM, Mal BC (2007) Identification of critical erosion-prone areas in the small agricultural watershed using USLE, GIS, and remote sensing. Water Resour Manage 21:729-746

Pandey A, Mathur A, Mishra SK, Mal BC (2009) Soil erosion modeling of a Himalayan Watershed using RS and GIS. Environ Earth Sci 59:399-410

Patil SL (2005) Soil erosion Andhra Pradesh. NBSS\&LUP, NagpurBangalore, and CSWCRTI, Dehra Dun-Bellary. https://doi.org/ 10.13140/RG.2.1.1616.2001

Perović V, Životić L, Kadović R, Dordević A, Jaramaz D, Mrvić V, Todorović M (2011) Spatial modeling of soil erosion potential in a mountainous watershed of South-eastern Serbia. Environ Earth Sci 68:115-128

Prasannakumar V, Vijith H, Abinod S, Geetha N (2012) Estimation of soil erosion risk within a small mountainous sub-watershed in Kerala, India, using the Revised Universal Soil Loss Equation (RUSLE) and geo-information technology. Geosci Front 3:209-215

Quispe D, Pérez-López R, Silva LF, Nieto J (2012) Changes in the mobility of hazardous elements during coal combustion in Santa Catarina power plant (Brazil). Fuel 94:495-503

Raju AS (2012) Current status of soil management in Andhra Pradesh. Bharathi Integrated Rural Development Society. Strategic pilot on adaption to climate change, pp 24-36

Rao AS (2003) Polycyclic aromatic hydrocarbons in sediments from Kolleru wetland in India. Bull Environ Contam Toxicol 70:964-971

Rao AS, Pillala RR (2001) The concentration of pesticides in sediments from Kolleru Lake in India. Pest Manag Sci 57:620-624

Rao RJ, Jairath J, Umesh P (2006) Pollution through aquaculture: Kolleru Wildlife Sanctuary. Econ Political Wkly 41:585-587

Renard K, Foster G, Weesies G, McDool D, Yoder D (1997) Predicting soil erosion by water: a guide to conservation planning with the revised Universal Soil Loss Equation (RUSLE). Agricultural Handbook 703, USDA-ARS

Restrepo JD, Escobar HA (2018) Sediment load trends in the Magdalena 418 River basin (1980-2010): anthropogenic and climateinduced causes. Geomorphology 419:76-91

Ribeiro J, Flores D, Ward C, Silva LFO (2010) Identification of nanominerals and nanoparticles in burning coal waste piles from Portugal. Sci Total Environ 408:6032-6041

Richard K (1993) Sediment delivery and the drainage network. In: Beven K, Kirkby MJ (eds) Channel network hydrology. Wiley, Chichester, pp 222-254

Rodriguez-Iruretagoiena A, De Vallejuelo S, De Diego A, De Leão F, De Medeiros D, Oliveira M, Taffarel S, Arana G, Madariaga J, Silva LF (2016) The mobilization of hazardous elements after a tropical storm event in a polluted estuary. Sci Total Environ 565:721-729

Roehl JW (1962) Sediment source areas, delivery ratios, and influencing morphological factors. In: Symposium of Bari (1-8 October 1962), 202-213. IAHS Publ. no. 59 
Sanchís J, Boovi D, Al-Harbi NA, Silva LF, Farré M, Barceló D (2013) Quantitative trace analysis of fullerenes in river sediment from Spain and soils from Saudi Arabia. Anal Bioanal Chem 405:5915-5923

Sanchís J, Oliveira LF, De Leão F, Farré M, Barceló D (2015) Liquid chromatography-atmospheric pressure photoionizationorbitrap analysis of fullerene aggregates on surface soils and river sediments from Santa Catarina (Brazil). Sci Total Environ 505:172-179

Sekhar KC, Chary NS, Kamala CT, Raj SDS, Rao AS (2004) Fractionation studies and bioaccumulation of sediment-bound heavy metals in Kolleru Lake by edible fish. Environ Int 29:1001-1008

Setegn SG, Dargahi B, Srinivasan R, Melesse AM (2010) Modeling of sediment yield from Anjeni-Gauged Watershed, Ethiopia using SWAT model. J Am Water Resour Assoc 46(3):514-526

Seutloali KE, Beckedahl HR (2015) Understanding the factors influencing rill erosion on road cuts in the south-eastern region of south-Africa. Solid Earth 6:633-641

Sharma A (2010) Integrating terrain and vegetation indices for identifying potential soil erosion risk area. Geo Spatial Inf Sci 13(3):201-209

Sheikh AH, Palria S, Alam A (2011) Integration of GIS and Universal Soil Los Equation (USLE) for Soil Loss Estimation in a Himalayan Watershed, vol 3, pp 51-57

Shen Z, Qiu J, Hong Q, Chen L (2014) Simulation of spatial and temporal distributions of non-point source pollution load in the Three Gorges Reservoir Region. Sci Total Environ 493:138-146

Shin GJ (1999) The analysis of soil erosion analysis in the watershed using GIS, Ph.D. Dissertation, Department, of Civil Engineering, Gang-won, National University

Silva LFO, Fdez-Ortiz De Vallejuelo S, Martinez-Arkarazo I, Castro K, Oliveira MLS, Sampaio C, De Brum I, De Leão F, Taffarel S, Madariaga J (2013) Study of environmental pollution and mineralogical characterization of sediment rivers from Brazilian coal mining acid drainage. Sci Total Environ 447:169-178

Sorando R, Comín FA, Jiménez JJ, Sánchez-Pérez JM, Sauvage S (2019) Water resources and nitrate discharges in relation to agricultural land uses in an intensively irrigated watershed. Sci Total Environ 659:1293-1306

Weesies GA (1998) Predicting soil erosion by water: A guide to conservation planning with the Revised Universal Soil Loss Equation (RUSLE). Agriculture Handbook No. 703. Washington, District of Columbia

Welde K, Gebremariam B (2017) Effect of land use land cover dynamics on the hydrological response of watershed: a Case study of Tekeze Dam watershed, northern Ethiopia. Int Soil Water Conserv Res 5:1-16

WilliamsJ R (1995) Chapter 25: The EPIC model. In Singh VP (ed) Computer models of watershed hydrology. Water Resources Publications, pp 909-1000

Wischmeier WH, Smith DD (1978) Predicting rainfall erosion lossesa guide to conservation planning. Agriculture Handbook No.537. US Department of Agriculture Science and Education Administration, Washington, DC, USA

Zhang WB, Fu JS (2003) Rainfall erosivity estimation under different rainfall amount. Resour Sci 25(1):35-41

Zhao G, Mu X, Wen Z, Wang F, Gao P (2013) Soil erosion, conservation, and eco-environment changes in the loess plateau of China. Land Degrad Dev 24:499-510

Publisher's Note Springer Nature remains neutral with regard to jurisdictional claims in published maps and institutional affiliations. 